Oksana Vitriak, Candidate of Technical Sciences, Associate Professors, Kyiv National University of Trade and Economics, 19, Kyoto str., Kyiv, 02156, Ukraine,

ORCID: 0000-0002-6614-1928;

ResearcherID: N-4003-2016

Liubov Tkachenko, Candidate of Technical Sciences, Associate Professors, Kyiv National University of Trade and Economics, 19, Kyoto str., Kyiv, 02156, Ukraine, ORCID: 0000-0003-2731-1178,

ResearcherID: N-4070-2016

Liudmyla Diachuk, Candidate of Philological Sciences, Associate Professor Department of Foreign Philology and Translation Kyiv National University of Trade and Economics 19, Kyoto str., Kyiv, 02156, Ukraine

ORCID: 0000-0002-0076-5236

ResearcherID: N-1723-2016

\title{
SPICE EXTRACTS IN UKRAINIAN CULINARY
}

The article describes the characteristics of classic spices, such as cloves and nutmeg, and presents the study of optimal parameters in the processes of extraction of biologically active substances from spicy-aromatic raw materials for use in Ukrainian cuisine.

Keywords. Spicy-aromatic plants, spices, extraction, cloves, nutmeg.

Relevance of the research topic. Since ancient times, spicy aromatic plants or spices have been widely used in cooking to give flavor and taste to dishes; they emphasize and offset the natural taste of a dish while creating the subtlest harmony. In their cooking, people from all over the world would use spices which were as highlyprized as gold, silver, fur, and silk. [1]

Spicy-aromatic plants contain aromatic or burning flavoring substances (essential oils, glycosides, tannins, etc.): cloves, black pepper, vanilla, cinnamon, ginger, and nutmeg that grow in the tropics. The roots (horseradish), rhizomes (sweet flag, ginger), bark (cinnamon), flower buds (cloves, capers), nuts and stigmas (saffron), leaves (laurel), fruits and their parts (red pepper), dried seeds (mustard, anise, caraway) are used as spices. 
These plants have been used for over the millennia for human welfare. They not only improve our food, but also have a rich history of medicinal use. Consumption of spicy-aromatic plants together with food acts on the physiological and psychological state of our body, promotes better digestion of food, stimulates cleansing, metabolism, and immune function of the body. Spicy-aromatic plants have the ability to inhibit bacteria (bactericidal), mainly saprogenic bacteria, and thus contribute to a longer conservation of food (conservation). However, the vast majority of spicy-aromatic plants have the ability to activate the removal of various types of waste from the body, carry out mechanical and biological decontamination, and serve as catalysts for enzymatic processes. The use of spicy-aromatic plants with food affects the physiological and psychological state of our body, promotes better absorption of food, and stimulates cleansing, metabolism and immune function of the body. [1]

Formulation of the problem. Spices are divided into classic (exotic) and local. Classic, or exotic, spices have been used since ancient times and have become widespread and classic in the vast majority of national cuisines. Local spices, for the most part, have a historically and geographically much smaller range of usage, or are used exclusively on site and cannot be subjected to long-range transportation.

Ukraine, in particular, has a range of locally grown and used spicy plants: parsley, garlic, dill, capsicum, celery, coriander, parsnip, fennel, sage, anise, caraway seeds, mint, etc. They are mainly used when still fresh.

At the same time, many classic spices that became international in use are used in Ukrainian cuisine. Their essential feature is that they are all used in cooking in preprocessed and necessarily dry form, which makes it possible for them to be stored and transported over long distances. Such spices include cloves and nutmeg, which are widely used in Ukrainian cuisine (in desserts, dough products, beverages, as well as for flavoring meat, vegetable, and mushroom dishes).

The objective characteristics of spices that distinguish them from seasonings and aromatic substances are the following: spicy aromatic plants are not used in significant quantities as condiments (for instance, barberry, plum, quince, pomegranate); spicy-aromatic plants cannot serve as a stand-alone dish (as an example, tomato paste or bell peppers); spicy-aromatic plants are used only as additives needed to give food a certain flavor accent. Attempts to increase the amount (dose) of spices can lead to a dramatic change in their qualitative effect on food, such as sharp unpleasant bitterness instead of a pleasant desired flavor. [6]

Therefore, it is relevant to study the processes of extraction of biologically active substances from spicy-aromatic raw materials for use in Ukrainian cuisine.

Analysis of recent research and publications. It is known that the release of biologically active substances from dry vegetable raw materials to the extract is influenced by the following factors: nature of the solvent, ratio of raw materials and extractant, temperature and duration of the process. The results of research into the processes of extraction of biologically active substances from spicy-aromatic 
vegetable raw materials with different extractants in different ratios of raw materials to extractant, in the conditions of extraction intensification are: the degree of grinding of raw materials to $0,5 \ldots 1,0 \mathrm{~mm}$, at temperatures of $20-100^{\circ} \mathrm{C}$ at different durations are given in the works of scientists $[3,4,5]$. Unfortunately, the process of extracting biologically active substances from aromatic raw materials, specifically dry spices such as cloves and nutmeg, has not been sufficiently studied.

Presenting main material. The purpose of our study was to obtain extracts from spicy-aromatic plants - cloves and nutmeg; determine optimal extraction parameters - temperature and process duration. The following criteria were selected to evaluate the quality of the extraction process: high organoleptic characteristics of the extract, yield of extractives, availability and simplicity of extraction technology.

Clove is rich in vitamins and minerals. Its main value is a large amount of protein (almost 6\%), it contains $\mathrm{K}(141 \mathrm{mg}$ ) and vitamins: groups B (about $1.2 \mathrm{mg}$ ), E ( $8.8 \mathrm{mg}), \mathrm{A}(160 \mathrm{mg}), \mathrm{C}(0.2 \mathrm{mg})$. Clove flower buds contain up to $20 \%$ of essential oil with a delicate aroma, also tannins, fat and mucus.

Clove dissolves well, transferring its aroma and taste to the extract both in hot and in cold water, and in addition to that gives color (brown).

Nutmeg seeds contain $3 \%$ of essential oil, about $40 \%$ of solid fatty oil. It has a very rich vitamin composition: 7 vitamins of group B, as well as vitamins PP, E, N. Minerals are presented in sufficient quantities: calcium, magnesium, potassium, phosphorus, sulfur, chlorine, sodium, iron, silicon, manganese, zinc, aluminum, copper, strontium, iodine, selenium, molybdenum, boron, vanadium, cobalt, nickel, tin, titanium, zirconium. Nutmeg contains essential and fatty oils, starch, pectin, dyes. [2]

Nutmeg essential oil contains many aromatic and biologically active substances that have different properties and interact with each other. Moreover, nutmeg contains nutrients that have a narcotic effect on the human nervous system. [2]

It is established that the effectiveness of extraction is influenced by: nature of the extractant, degree of grinding of raw materials, temperature and duration of extraction, hydrodynamic conditions, structure of plant material, ratio of raw materials to extractant (hydromodule).

Water was selected as the extractant. Intensive dissolution of flavoring compounds, such as carbohydrates, essential oils, aromatic soluble components, pigments, tannins, organic acids, as well as antioxidants, trace elements, in the solution results in mixing crushed raw material with water.

The study was carried out as follows. Prepared spices were divided into two fractions: clove, ground to powder and pieces of $7 \mathrm{~mm}$; nutmeg, ground to powder and $5 \mathrm{~mm}$ pieces. The test samples were pored over with distilled water heated to the required temperature in separate flasks with tightly ground corks. The temperature of the extractant was changed from 30 to $80^{\circ} \mathrm{C}$. The ratio of raw material to extractant (hydromodule) in the experiments was: 1:1, 1:5, 1:10. For 30 minutes, every 5 minutes the samples were taken to determine the solids content of the extract. 
The analysis of the obtained results shows that the most acceptable is grinding cloves and nutmeg to the state of powder, with the effective transition of the extractive substances into the solution. This is due to a greater degree of cell damage and an increase in the surface area of the particles.

Due to the ratio of liquid to solid phases 1:1, 1:5 complete immersions of cloves and nutmeg in the water did not occur, and extraction took place in the surface layers of spices. In this case, a mushy mass was formed, which reduced the quality of filtration.

The rate of transfer of the extractives to the extract was also influenced by the temperature of the extractant. In determining the required extraction temperature, the feasibility of energy costs and thermal sensitivity of the target components of the spices were taken into account. At temperatures below $40^{\circ} \mathrm{C}$, the yield of biologically active substances decreased. It is advisable to extract biologically active substances from clove and nutmeg at temperatures not exceeding $60^{\circ} \mathrm{C}$.

Therefore, the most effective conditions for extraction of extractives from clove and nutmeg are: grinding to a powder state, hydromodule 1:10, extractant temperature $60^{\circ} \mathrm{C}$.

Thus, in the first experiment with clove crushed to powder state, the rapid transition of substances from solid to liquid phase lasted up to 20 minutes, the maximum amount of extractants was infused after 25 minutes from the start of extraction. Grinding cloves to $7 \mathrm{~mm}$ was not effective (the second experiment), $4.5 \%$ of solids from the maximum number of extractives in the extract of the first experiment passed to the solution.

In experiments with nutmeg, the maximum number of solids in the solution was reached 25 minutes after the start of extraction. Almost $11 \%$ of the solids were transferred to the solution with ground nutmeg up to $5 \mathrm{~mm}$ after 10 minutes from the beginning of the extraction, and further extraction was not effective.

Organoleptic and physico-chemical parameters were determined for the obtained extracts of clove and nutmeg (hydromodule 1:10; extraction temperature $60^{\circ} \mathrm{C} ; 25 \mathrm{~min}$ extraction time): appearance and consistency - opaque turbid liquids without fibers and suspended particles; color - brown, close to the raw material; odor - inherent in raw materials.

Conclusions. According to the results of the conducted research, it was found expedient to obtain extracts from dried spicy-aromatic plants (carnations and nutmeg); the most efficient and optimal methods of extraction are established (grinding to powder state; hydromodule 1:10; extraction temperature $60^{\circ} \mathrm{C}$; extraction time $25 \mathrm{~min}$.). The obtained extracts are found to be advantageous for use in Ukrainian culinary. 


\section{REFERENCES}

1. Dzhon O'Konnell. Entsiklopediya spetsiy. Ot anisa do shalfeya // Per. s angl. - Minsk: Litagent, 2017. - 352 s.

2. Gataulína G. Muskatnyy orekh: svoystva, deystviye, sostav, muskatnykh orekh v kulinarii. Rezhim dostupu: http://www. inflora. ua

3. Ivanova V. Bezalkohol'ni napoyi na osnovi fitoekstraktiv / V. Ivanova // Tovary i rynky. - 2011. - № 2. - S. 69-74.

4. Osypova L. A. Udoskonalennya pererobky pryano-aromatychnoyi syrovyny v tekhnolohiyi napoyiv ta vyn iz funktsional'nymy vlastyvostyamy / L. A. Osypova // Prohresyvni tekhnika ta tekhnolohiyi kharchovykh vyrobnytstv restorannoho hospodarstva i torhivli: zb. nauk. pr. / Khark. derzh. un-t kharchuvannya ta torhivli ; [redkol. : O. I. Cherevko (vidpov. red. ) ta in. ]. - Kharkiv, 2013. - Vyp. 2 (18). S. 237-245.

5. Viluchennya bíologíchno aktivnikh rechovin z líkars'kikh trav shlyakhom yekstraguvannya ta nastoyuvannya / M. M. Zheplíns'ka, L. V. Zotkína, G. M. Bíla, M. V. Íshchenko // Kharchova promislovíst'. - 2012. - Vip. 12. - 35-41 s.

6. Yekstraktsíya roslinnoï sirovini / YU. Í. Sidorov, Í. Í. Gubits'ka, R. T. Konechna, V. P. Novíkov. - L'vív: Vidavnitstvo L'vívs'koï polítekhníki, 2008. $336 \mathrm{~s}$.

7. Yurkanís L. Pryanost' gvozdika: sostav, svoystva i pol'za, protivopokazaniya, gvozdika v kulinarii. Rezhim dostupu: http://www. inflora. ua 